\title{
Nitric Oxide Inhibits Viral Replication in Murine Myocarditis
}

\author{
Charles J. Lowenstein, ${ }^{\star}$ Susan L. Hill, ${ }^{\sharp \mid}$ Anne Lafond-Walker, ${ }^{\star \S}$ Jean Wu, ${ }^{\star \S}$ Greg Allen, ${ }^{\star \|}$ Mike Landavere, ${ }^{\ddagger \mid}$ Noel R. Rose, ${ }^{\ddagger}$ \\ and Ahvie Herskowitz ${ }^{\star \ddagger} \|$ \\ *Division of Cardiology, Department of Medicine; ${ }^{*}$ Department of Pathology, ${ }^{\S}$ School of Medicine; and $\|^{\text {Department of Molecular }}$ \\ Microbiology and Immunology, School of Hygiene and Public Health, The Johns Hopkins Medical Institutions, Baltimore, Maryland \\ 21205
}

\begin{abstract}
Nitric oxide (NO) is a radical molecule that not only serves as a vasodilator and neurotransmitter but also acts as a cytotoxic effector molecule of the immune system. The inducible enzyme making NO, inducible NO synthase (iNOS), is transcriptionally activated by IFN- $\gamma$ and TNF- $\alpha$, cytokines which are produced during viral infection. We show that iNOS is induced in mice infected with the Coxsackie B3 virus. Macrophages expressing iNOS are identified in the hearts and spleens of infected animals with an antibody raised against iNOS. Infected mice have increased titers of virus and a higher mortality when fed NOS inhibitors. Thus, viral infection induces iNOS in vivo, and NO inhibits viral replication. NO is a novel, nonspecific immune defense against viruses in vivo. (J. Clin. Invest. 1996. 97:1837-1843.) Key words: enterovirus $\bullet$ Coxsackievirus $\bullet$ macrophage $\bullet$ cytokines $\bullet$ inducible nitric oxide synthase
\end{abstract}

\section{Introduction}

Nitric oxide $(\mathrm{NO})^{1}$ is a radical molecule produced by a variety of cells. NO acts as a neurotransmitter, a vasodilator, and as a cytotoxic immune effector (1-6). NO is produced by NO synthase (NOS), which occurs as several isoforms. The constitutive isoforms, such as endothelial NOS and neuronal NOS, are regulated by $\mathrm{Ca}^{2+}$ and calmodulin. We and others have cloned the inducible isoform (iNOS) from murine macrophages (7-9). iNOS is present in activated but not resting macrophages, and it always produces NO when synthesized, so its activity is transcriptionally regulated. We and others isolated the promoter region flanking the iNOS gene and showed that it contains response elements capable of binding transcription factors induced by viral infection, such as nuclear factor- $\mathrm{B}$ and IFN response factor-1 $(10,11)$. The presence of sequences that potentially activate iNOS transcription in response to viral infection suggests that NO plays a role in responding to viruses.

Address correspondence and reprint requests to Charles J. Lowenstein, Division of Cardiology, Department of Medicine, Johns Hopkins University School of Medicine, 950 Ross Building, 720 Rutland Avenue, Baltimore, MD 21205. Phone: 410-955-1530; FAX: 410-9550485.

Received for publication 24 November 1993 and accepted in revised form 26 January 1996.

1. Abbreviations used in this paper: CVB3, Coxsackievirus strain B type 3; iNOS, inducible nitric oxide synthase; NAME, $N^{\mathrm{G}}$-nitro-arginine methyl ester; NMMA, $N^{\mathrm{G}}$-mono-methyl-arginine; NO, nitric oxide; NOS, NO synthase.

J. Clin. Invest.

(C) The American Society for Clinical Investigation, Inc.

0021-9738/96/04/1837/07 \$2.00

Volume 97, Number 8, April 1996, 1837-1843
We used a murine model of viral myocarditis to explore the role of NO during viral infection. The B10.A mouse, when treated with LPS at the time of infection with Coxsackie virus B3 (CVB3), develops maximum viremia within $3 \mathrm{~d}$ and can die within 7-10 d. With this system we show that macrophages within myocarditic infiltrates express NOS in virally infected mice, and that inhibition of NOS both increases mortality and accelerates the time course of mortality. The viral load is increased in infected mice that are fed NOS inhibitors, suggesting that NO inhibits viral replication in vivo, as has been reported with in vitro studies by others (12-15).

\section{Methods}

Materials. The iNOS cDNA was previously cloned by our laboratory (7). The antibody hybridizing to a subpopulation of macrophages expressing MAC-3 was prepared from a hybridoma cell line from American Type Culture Collection (ATCC; Rockville, MD; M3/ 84.6.34) (16). The antibody hybridizing to cells expressing the common leukocyte antigen (CLA) antibody was prepared from a hybridoma cell line from ATCC (M1/9.3.4.HL.2) (17). The antibody hybridizing to cells expressing the 5E6 natural killer cell antigen was obtained from PharMingen (San Diego, CA; 01621D) (18).

Production of an anti-iNOS antibody. A rabbit polyclonal antiiNOS peptide antibody was produced using methods previously described $(19,20)$. In brief, a peptide corresponding to the $\mathrm{COOH}$ terminal 15 amino acids of iNOS was synthesized (AKKGSALEEPKATRL) and coupled to thyroglobulin. The conjugate was injected with complete Freund's adjuvant into a New Zealand White rabbit; a booster injection was repeated at monthly intervals, and serum was collected $1 \mathrm{wk}$ afterwards (Hazelton Research, Inc., Denver, PA). The antibody was purified from the serum using an affinity column of peptide conjugated to BSA.

Immunohistochemistry and Western blots. Western blot analysis was performed as described previously (19). In brief, $200 \mu \mathrm{g}$ of macrophage homogenate was fractionated by SDS-PAGE and then transferred to a nylon membrane, blocked and washed, incubated with the anti-iNOS antibody at a dilution of 1:2,500, and developed with a chemiluminescent system (ECL; Amersham Corp., Arlington Heights, IL; according to the manufacturer's instructions). Immunohistochemistry was performed as described previously (19). In brief, tissue from paraformaldehyde-perfused mice was frozen in O.C.T. medium, and $4-\mu \mathrm{m}$-thick serial sections were cut. The tissue slices were mounted on slides, blocked with BSA, incubated with rabbit anti-murine iNOS antibody at dilutions of 1:250, washed, incubated with a secondary biotinylated goat anti-rabbit antibody, washed, incubated with a streptavidin-horseradish peroxidase conjugate, and developed with a kit (Vector Laboratories, Inc., Burlingame, CA; according to the manufacturer's instructions). As controls, tissues were processed similarly with the primary antibody omitted. For quantitation of cellular infiltrates, transverse sections of murine left ventricle were examined at the level of the papillary muscles. A minimum of 20 high-powered fields $(\times 400)$ were examined, and the total number of positive-staining cells per field was counted.

NOS catalytic activity assay. NO production was measured by monitoring the conversion of $\left[{ }^{3} \mathrm{H}\right]$ arginine to $\left[{ }^{3} \mathrm{H}\right]$ citrulline as described previously (21). In brief, tissue or cell samples were homoge- 
nized in Tris-EDTA buffer; the homogenate was added to a mixture of NADPH, EDTA, and $5 \times 10^{4} \mathrm{cpm}\left[{ }^{3} \mathrm{H}\right]$ arginine (New England Nuclear, Boston, MA), and incubated at $22^{\circ} \mathrm{C}$ for $15 \mathrm{~min}$. The reaction mixture was run over a column of Dowex 50XW mesh 200-400 (Sigma Chemical Co., St. Louis, MO), and the $\left[{ }^{3} \mathrm{H}\right]$ citrulline in the flow-through was counted in a scintillation counter.

Viral culture. CVB3 was maintained in our laboratory $(22,23)$. Aliquots of virus (generous gift of Dr. S. Huber, University of Vermont, Burlington, VT) were plated onto HeLa cells, and the virus was collected from the supernatant and cells, centrifuged, and stored at $-70^{\circ} \mathrm{C}$. Viral virulence was measured by intraperitoneal injection into B10.A mice.

Macrophage culture and stimulation. RAW 264.7 macrophages (ATCC) were grown and stimulated as described previously (7). To prepare extracts of stimulated macrophages, $10-\mathrm{cm}$ plates of $10^{7}$ macrophages were stimulated for $8 \mathrm{~h}$ with $3 \mathrm{ng} / \mathrm{ml}$ LPS (Escherichia coli 0111:B4; Sigma Chemical Co.) and $10 \mathrm{U} / \mathrm{ml}$ recombinant murine IFN- $\gamma$ (gift of the American Cancer Society). The macrophages were then scraped from the plates, suspended in $1 \mathrm{ml}$ PBS, and homogenized in a Dounce homogenizer (Kontes Glass Co., Vineland, NJ).

Murine infection. The murine model of CVB3 myocarditis has been extensively studied in our laboratory (22-25). In brief, B10.A mice were injected intraperitoneally with a dilution of CVB3 virus standardized to produce death in $50 \%$ of the animals by day 7 . On day 2 , the mice were injected intraperitoneally with $1 \mu \mathrm{g}$ LPS. Some mice were fed NOS inhibitors in their drinking water (26). Either 10 $\mathrm{mM} N^{\mathrm{G}}$-mono-methyl-arginine (NMMA; Calbiochem Corp., La Jolla, CA) or $100 \mathrm{mM} N^{\mathrm{G}}$-arginine methyl ester (NAME; Sigma Chemical Co.) was supplied as drinking water to control or infected mice. (In later experiments, lower doses of methyl-arginine were used as described in figure legends.) The amount of water consumed and the weight of the mice were recorded to ensure that morbidity and mortality did not reflect differences in hydration. For determining viral content of the hearts of infected mice, mice were killed $5 \mathrm{~d}$ after infection, a time point previously determined to be associated with peak cardiac viral titers; $1 \mathrm{~g}$ of heart was homogenized in $1 \mathrm{ml} 2 \%$ MEM medium (GIBCO BRL, Gaithersburg, MD); and $20 \mu \mathrm{l}$ was assayed for viral titer. Viral quantity was then determined by titering homogenate on HeLa cells; serial dilutions were made until a reduction from 100 to $50 \%$ of cytopathic effect was seen. To measure the induction of NOS by viral infection, B10.A mice were injected intraperitoneally with $1 \mathrm{ml}$ of HeLa cell supernatant containing CVB3. Hearts and spleens were harvested from control and infected mice $7 \mathrm{~d}$ after infection.

Statistics. A Student's $t$ test was used to assess differences in viral titers in hearts between groups of mice given different amounts of NMMA (see Table II). An ANOVA analysis was used to assess differences in individual cell markers between groups of infected animals at different time points (see Table III). In all tests, $P$ values of 0.05 or less were considered to indicate statistical significance.

\section{Results}

Viral infection activates iNOS in the heart. CVB3 elicits myocarditis in humans (27) and mice (22-25). We treated B10.A mice with CVB3 and LPS, and $7 \mathrm{~d}$ later we assayed the spleen and heart for NOS catalytic activity (Fig. 1). In infected mice, negligible NOS activity occurs in the spleen, whereas a massive increase in NOS activity is evident in the heart. Of the several forms of NOS, the neuronal and endothelial enzymes are absolutely dependent upon $\mathrm{Ca}^{2+}$, whereas iNOS activity is independent of $\mathrm{Ca}^{2+}$. Treatment with the chelating agent EDTA fails to decrease cardiac NOS activity in tissue from infected animals. Indeed, a modest increase of NOS activity that is consistently evident in several replications occurs with EDTA

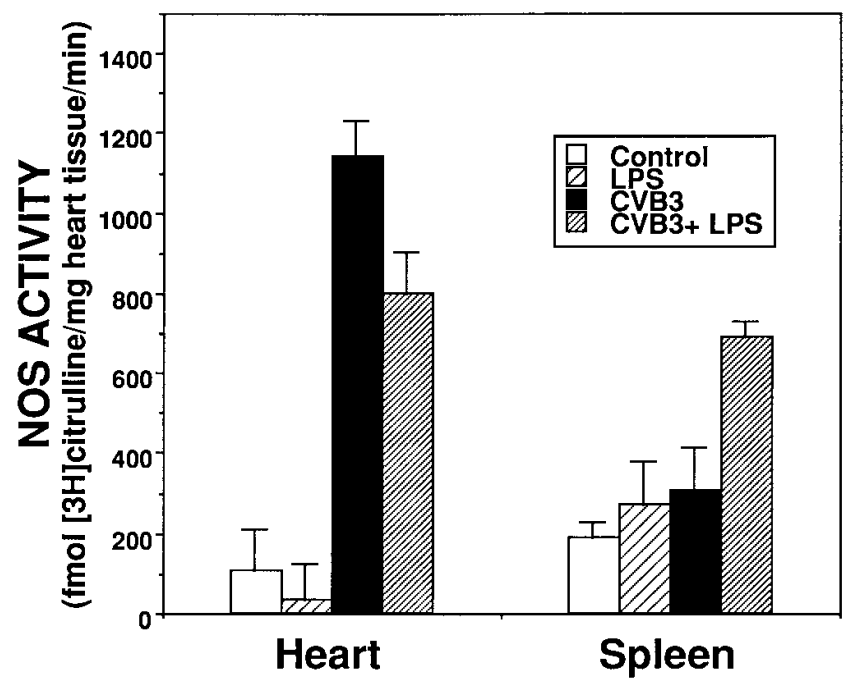

Figure 1. NOS catalytic activity in myocarditis. Hearts and spleens were collected from control and CVB3-infected B10.A mice on day 7 and assayed for iNOS catalytic activity in the presence of EDTA to abolish constitutive NOS activity. $n=3$ mice per data point \pm SEM; $P<0.05$ for CVB3 and CVB3 + LPS hearts vs controls.

(data not shown). The mechanism for this increase is not apparent.

We wished to ascertain whether the activated NOS in the hearts was derived from macrophages and to localize the cellular elements producing NOS using immunohistochemistry. Accordingly, we developed antisera in rabbits immunized with a peptide whose sequence occurs in iNOS but not in neuronal or endothelial NOS. Affinity-purified antibodies were used in Western blots of macrophages in culture stimulated with LPS and IFN- $\gamma$ for various times (Fig. 2). A band corresponding in molecular weight to iNOS, $\sim 135 \mathrm{kD}$, is first evident at $4 \mathrm{~h}$ and becomes progressively more intense at 6 and $24 \mathrm{~h}$. This corresponds to the known time course for induction of new iNOS protein. Immunohistochemistry of the same populations of macrophages reveals negligible staining in unstimulated macrophages, whereas, $8 \mathrm{~h}$ after stimulation with LPS and IFN- $\gamma$, intense staining is evident in discrete regions of macrophage cytoplasm (Fig. 3).

Immunohistochemistry was used to localize cells expressing iNOS in the spleen and heart of virally infected mice (Fig.

\section{HOURS}

$M_{r}(k D)$
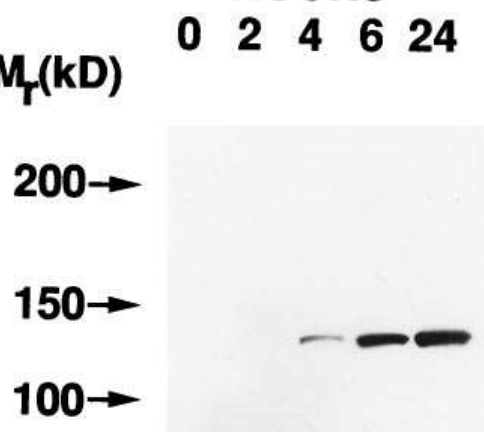

$75 \rightarrow$
Figure 2. Activated macrophage extracts express iNOS protein. Macrophages were stimulated with LPS and IFN- $\gamma$ for $0,2,4,6$, and $24 \mathrm{~h}$. Homogenates of macrophage were electrophoresed, transferred onto a membrane, and probed with anti-iNOS antibody. 

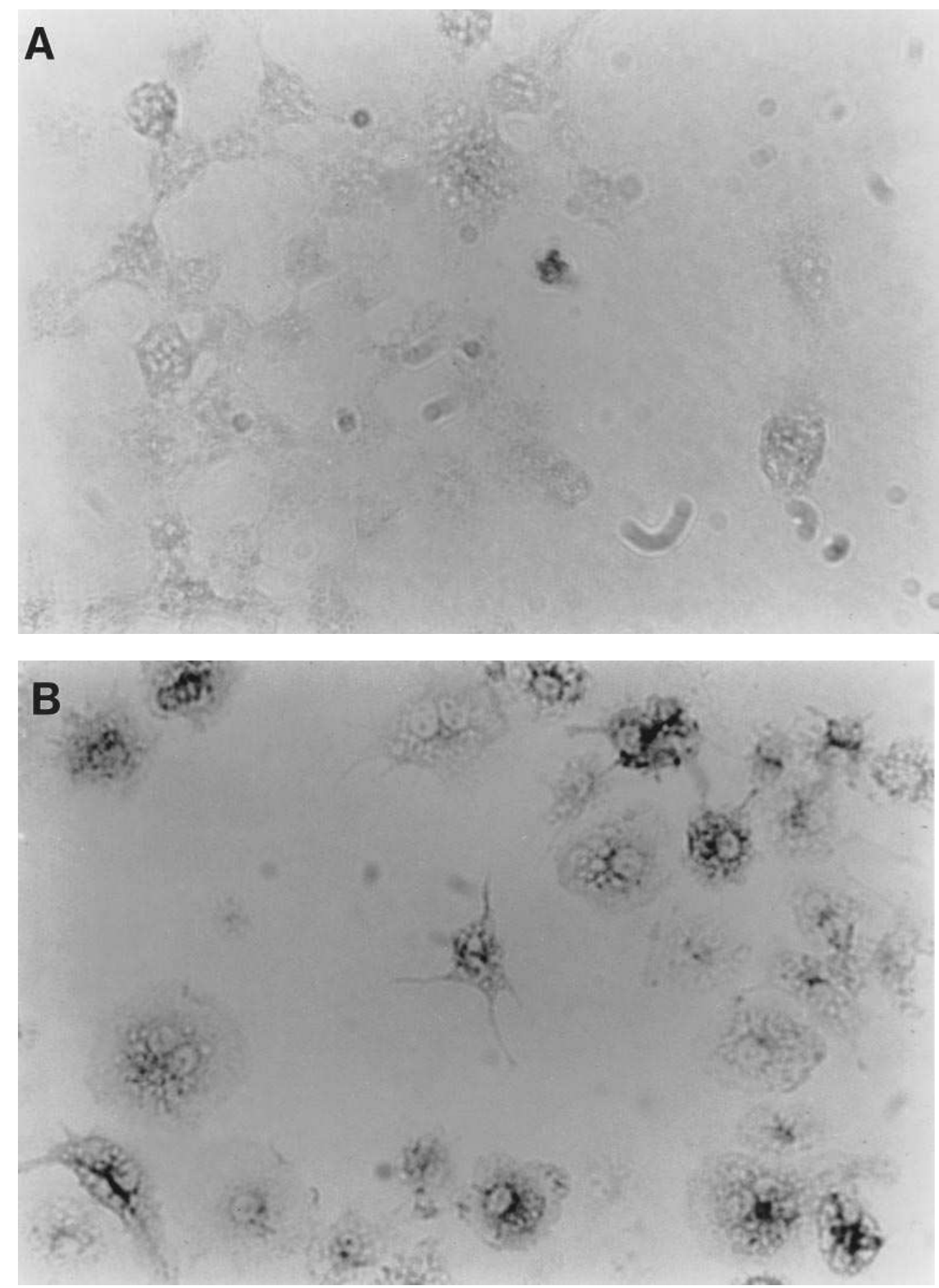

Figure 3. Activated macrophages express iNOS. Immunocytochemistry with the anti-iNOS antibody of macrophages $(A)$ resting and $(B)$ stimulated with LPS and IFN- $\gamma$ for $6 \mathrm{~h}$.

4). The spleen is comprised of circular germinal centers or white pulp enriched in lymphocytes, surrounded by the red pulp enriched in mononuclear cells. No iNOS staining is evident in the white pulp, whereas $\sim 1 \%$ of the mononuclear cells in the red pulp stains for iNOS (Fig. $4 A$ ). In infected mice, the architectural boundaries of white and red pulp are disrupted. Increased iNOS staining is evident, with $\sim 10 \%$ of the mononuclear cells staining positively (Fig. $4 \mathrm{~B}$ ). This corresponds with the iNOS mRNA localization that we reported previously (7).

In hearts of control mice, negligible iNOS staining is detected (Fig. $4 \mathrm{C}$ ), whereas prominent staining occurs in infected mice. Two staining patterns are seen in infected mice. Within focal zones of myocyte necrosis, infiltrating macro- phages stain intensely for iNOS. In addition, macrophages staining for iNOS are scattered throughout the interstitial spaces between nonnecrotic myocardial fibers (Fig. 4D). Focal zones of necrosis and diffuse interstitial mononuclear cell infiltrates are the classical histologic pattern found in CVB3 myocarditis in the LPS-treated B10.A murine strain $(24,25)$.

Since the mice were treated with LPS as well as virus and LPS alone can induce iNOS, we also examined mice treated with the same dose of LPS but no virus. In these animals, we do not observe iNOS staining in the heart (data not shown). We also examined mice treated with virus alone but no LPS. In these animals, iNOS was expressed in cardiac mononuclear cells (data not shown).

Like B10.A mice, A.SW mice develop myocarditis when 


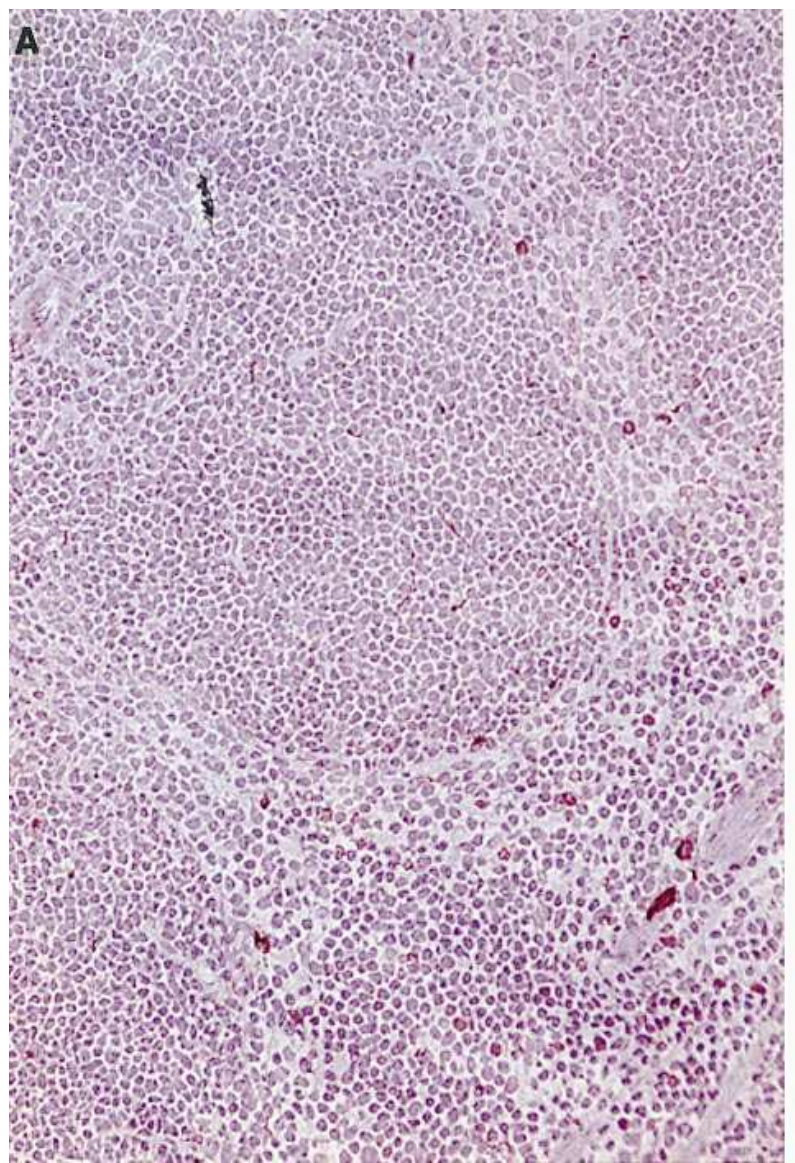

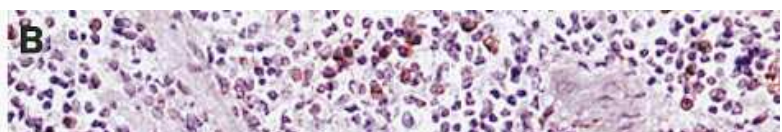

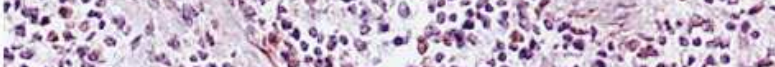

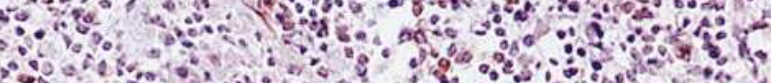

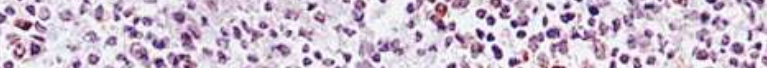
$00^{2} x^{2}$.

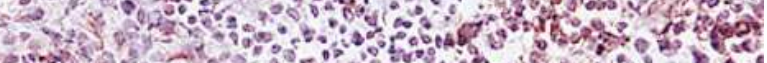
w5.

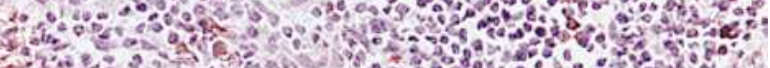

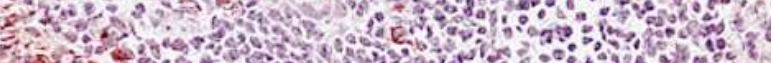

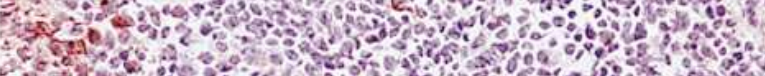
A 30 .

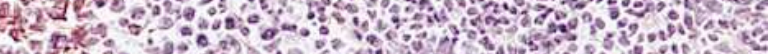
9.5

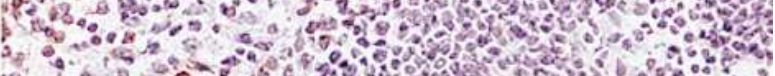

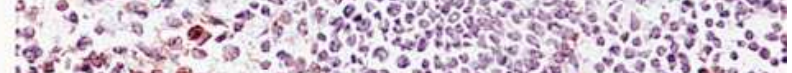

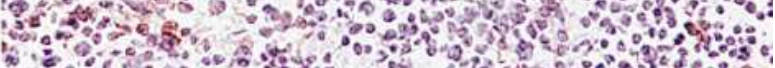

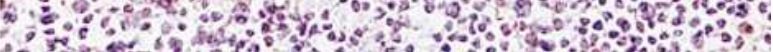

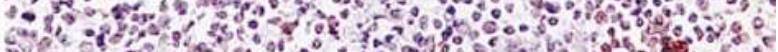

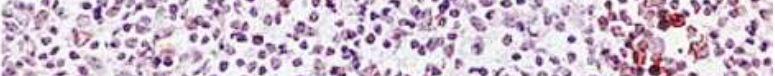

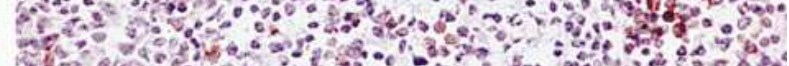

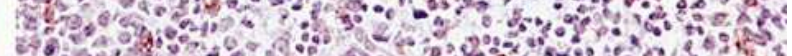

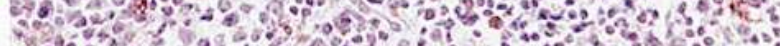

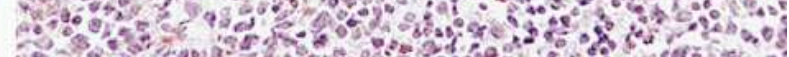
15 s

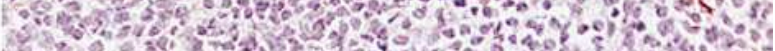

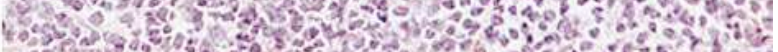

c)
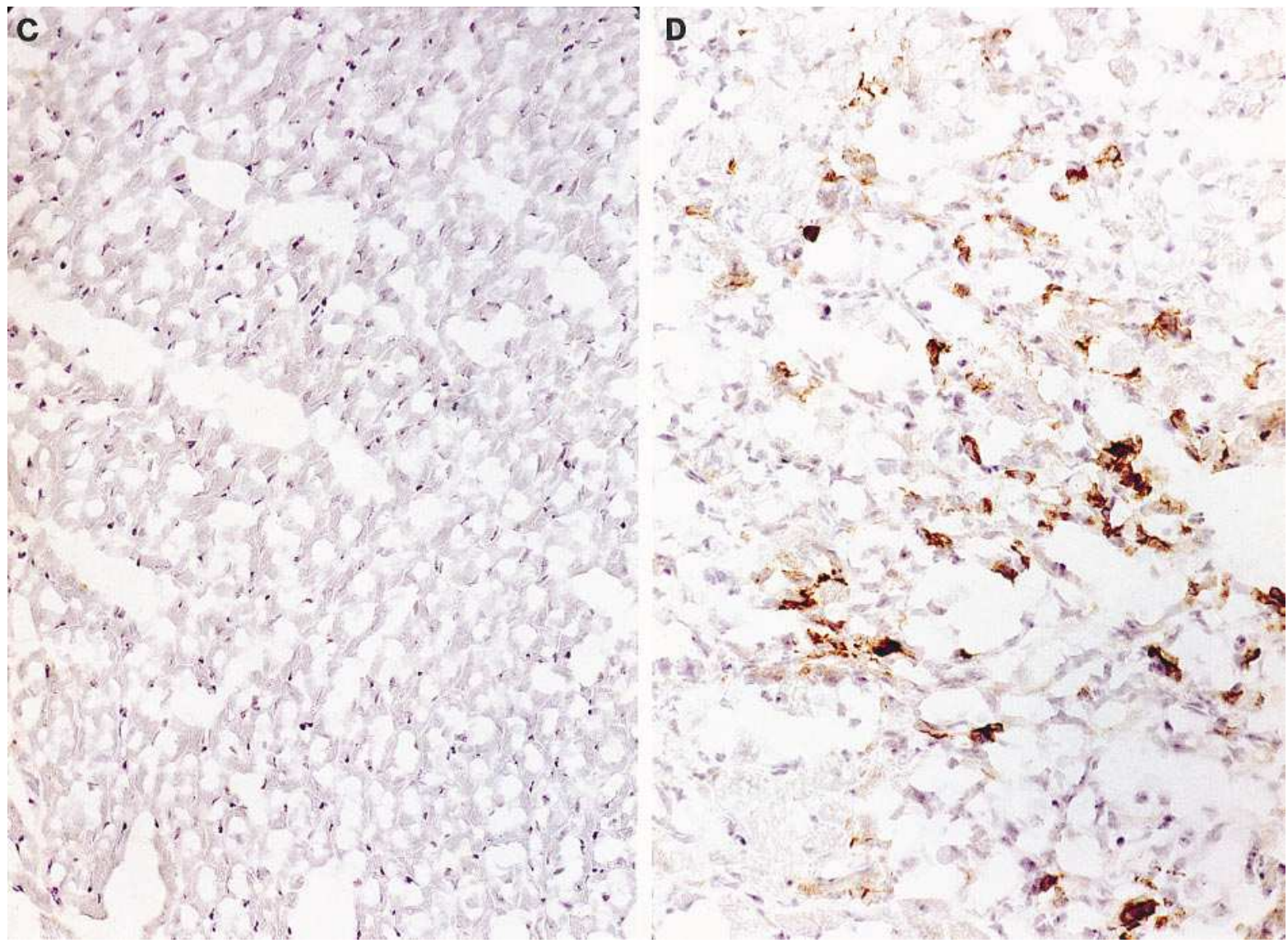
Table I. NOS Inhibitors Increase Mortality in CVB3-infected Mice

\begin{tabular}{ccccc}
\hline Group & Infection & LPS & Treatment & Death \\
\hline A & - & - & NAME & $1 / 6$ \\
B & - & - & NMMA & $0 / 6$ \\
C & - & + & NAME & $1 / 10$ \\
D & + & + & & $5 / 11$ \\
E & + & - & NAME & $10 / 10$ \\
F & + & + & NAME & $13 / 14$ \\
G & + & + & NMMA & $16 / 16$ \\
& & & &
\end{tabular}

Mice were infected with a fixed dose of Coxsackie virus, and their mortality was observed after $7 \mathrm{~d}$. Some mice were fed $10 \mathrm{mM}$ NMMA or 10 $\mathrm{mM}$ NAME in drinking water. Data are reported as dead mice/total mice for each data point.

treated with CVB3, although no boost with LPS is necessary for development of the late phase of myocarditis. In some experiments, we treated A.SW mice with CVB3 in the absence of LPS and examined their hearts $7 \mathrm{~d}$ later (data not shown). The pattern and extent of iNOS staining in the heart is essentially the same in these mice as in the B10.A mice.

NOS inhibitors increase mortality and viral titer. The activation of iNOS in the hearts of virally infected mice could represent an antiviral immune response or a postviral immune response that damages the heart. Discriminating between these alternatives might be feasible by ascertaining whether inhibition of NO formation is therapeutic or worsens the clinical state of the animals. Accordingly, we treated mice with two inhibitors of NOS, NMMA or NAME (Table I). Feeding NMMA or NAME to control or LPS-treated mice does not produce significant mortality. Viral infection alone produces $40-50 \%$ mortality. Virtually all infected animals treated with NAME or NMMA die.

To explore possible mechanisms for the increased mortality produced by NOS inhibitors, we monitored the viral titer in myocardial extracts of mice fed different amounts of NMMA (Table II). An increase in viral titer is evident with a $>1,000-$ fold increase of viral titer at the highest dose of NMMA.

NOS inhibitors increase inflammatory infiltrates in hearts of infected mice. To determine the effect of NOS inhibition upon the kinetics of immune cell infiltration into the heart, mice were harvested at days 3,5, and 9 after infection with CVB3; sections of their hearts were processed for immunohistochemistry with antibodies against the MAC-3, CLA, and natural killer markers; and the numbers of staining cells were counted per high-power field. Inhibition of NOS is associated with a mild increase in macrophages infiltrating into the heart after $3 \mathrm{~d}$ of infection and an increase in natural killer cells after 3 and $5 \mathrm{~d}$ of infection, but after $9 \mathrm{~d}$ of infection the numbers of cells expressing MAC-3, CLA, and natural killer markers are approximately equal (Table III). (The large standard deviations in cell counts are due to the focal nature of the disease.)
Table II. Inhibition of NOS Increases Viral Titer in Infected Mice

\begin{tabular}{lcc}
\hline Group & [NMMA] & $\begin{array}{c}\text { Log viral titer } \\
(50 \% \text { of tissue culture } \\
\text { infectious dose })\end{array}$ \\
\hline & $m M$ & \\
A & 0 & $3.3 \pm 0.2$ \\
B & 0.8 & $3.6 \pm 0.5$ \\
C & 4.0 & $3.2 \pm 0.2$ \\
D & 8.0 & $6.4 \pm 0.8$ \\
\hline
\end{tabular}

Mice were infected with Coxsackie virus and fed various doses of NMMA. After $5 \mathrm{~d}$, the viral content of $20 \mu \mathrm{g}$ heart was measured. $n=3$ for each data point \pm SEM; $P<0.02$ for $[\mathrm{NMMA}]=8 \mathrm{mM}$.

\section{Discussion}

Our study provides several lines of evidence indicating a major role for NO in defending against viral infections, at least in the case of Coxsackie virus myocarditis. Other investigators have reported that infection with various viruses induces expression of iNOS in vitro $(12,13,15,28-31)$. MacMicking and associates (13) have observed that transfection of iNOS cDNA into cells in culture decreases viral titer in these cells. Croen (12) observed that induction of iNOS in virally infected macrophages decreases viral titer in these cells.

We provide evidence that this antiviral effect of NO observed in vitro plays a role in an organism's response to viral infection. Thus, we show that viral infection produces a profound augmentation of iNOS in the heart. Evidence that NO protects the animal from damaging effects of early virus-mediated injury comes from our experiments in which NOS inhibitors increase viral titer and mortality.

$\mathrm{NO}$ is a prominent vasodilator that also inhibits platelet aggregation. One potential role of NO in inflammatory responses could be relatively nonspecific: namely, to increase vascular perfusion of the infected areas, permitting lymphocytes to infiltrate and produce selective antiviral antibodies. Some studies suggest that NO may reduce inflammatory responses by decreasing neutrophil adherence to endothelium (32-35). Our findings favor a direct antiviral role of NO in response to infection. This would fit with the established antibacterial effects of NO (36-41).

In this murine myocarditis model, viral infection stimulates infiltrating mononuclear cells to secrete IFN- $\gamma$, IL-1 $\beta$, IL-6, and TNF- $\alpha(24,25,42,43)$. In addition, CVB3-induced production of IL-1 $\beta$, IL- 6 , and TNF- $\alpha$ has been demonstrated in human monocytes (44). We (10) and others (11) have shown that the regulatory region of the iNOS gene contains specific recognition sites for transcription factors induced by IL-6, TNF- $\alpha$, and IFN- $\gamma$. By deletion analysis, we have shown regulatory functions for these regions in the induction of iNOS. The release of these cytokines from mononuclear cells probably stimulates the expression of iNOS during viral infection.

Figure 4. Infected mice express iNOS in their spleens and hearts on day 7. Immunohistochemistry with the anti-iNOS antibody shows that iNOS is absent in spleens of control mice $(A)$ but present in spleens from infected mice $(B)$. Control animals do not express iNOS in their heart $(C)$, but infected animals express iNOS in their hearts in an infiltrative pattern $(D)$. The magnification is 400 . Noninfected control mice given LPS alone on day 2 do not express iNOS in their heart on day 7 (data not shown). 
Table III. Effect of NOS Inhibition on Immune Cell Infiltration

\begin{tabular}{llrllr}
\hline Group & Marker & [NMMA $]$ & Day 3 & Day 5 & Day 9 \\
\hline & & $m M$ & & & \\
A & MAC-3 & 0 & $3.9 \pm 2.6$ & $3.6 \pm 0.1^{*}$ & $11.9 \pm 2.2$ \\
B & MAC-3 & 10 & $3.5 \pm 2.2$ & $8.3 \pm 1.6^{*}$ & $11.8 \pm 2.0$ \\
C & CLA & 0 & $6.6 \pm 1.5$ & $5.8 \pm 0.5$ & $14.4 \pm 2.2$ \\
D & CLA & 10 & $6.1 \pm 1.5$ & $4.7 \pm 0.9$ & $14.5 \pm 2.6$ \\
E & NK & 0 & $0.1 \pm 0.1^{\ddagger}$ & $0.9 \pm 0.7^{\S}$ & $7.7 \pm 4.4$ \\
F & NK & 10 & $0.4 \pm 0.3^{\ddagger}$ & $2.6 \pm 2.1^{\S}$ & $9.2 \pm 5.3$
\end{tabular}

Mice were infected with Coxsackie virus and fed 0 or $10 \mathrm{mM}$ NMMA $(n=4-6$ for each group \pm SD). Hearts were harvested at various times after infection and processed for immunohistochemistry with antibodies against macrophages, leukocytes, and natural killer cells. The number of cells staining for each marker was counted in at least 20 high-powered fields in transverse sections of left ventricles. More cells staining with the MAC-3 and natural killer markers are present in mice receiving NMMA early after infection, but after $9 \mathrm{~d}$ the numbers are roughly equal. $P<0.05$ for MAC-3 marker day $5^{*}$ for 0 vs $10 \mathrm{mM}$ NMMA, and for natural killer marker days $3^{\ddagger}$ and $5^{\S}$ for 0 vs 10 mM NMMA. $N K$, natural killer.

Cytokines can also induce iNOS expression in cardiac myocytes in vitro (45-47), and iNOS can be expressed in cardiac myocytes and microvascular endothelial cells in animal models of inflammation such as cardiac allograft rejection (48-50). However, by immunohistochemistry we did not detect iNOS expression in cardiac cells other than infiltrating mononuclear cells. It is possible that iNOS is expressed in cardiac myocytes at a low level that is not detected by immunohistochemistry but at a level sufficient to synthesize enough NO to block viral replication. Since the number of cardiac myocytes is much greater than the number of infiltrating mononuclear cells, a small amount of iNOS expressed in many cardiac myocytes could generate more NO than a large amount of iNOS in relatively few macrophages.

After induction of iNOS by cytokines, the elaborated NO elicits direct antiviral effects. This response would appear to reflect a rapid but nonspecific type of immune activity, contrasted with the slower but highly site-specific recognition actions of antibodies and $\mathrm{T}$ cell receptors.

How does NO inhibit viral replication? Conceivably, NO could exert an antiviral effect through its influences upon the host cell. NO can influence cell metabolism in several ways. It inhibits glyceraldehyde-3-phosphate dehydrogenase, thus diminishing glycolysis $(51-55)$, cis-aconitase $(56,57)$, and mitochondrial respiratory enzymes (58), and perhaps it can affect the Krebs cycle. As NO has been demonstrated to damage DNA (59-61), it can probably also damage viral RNA. The known ability of NO to inhibit ribonucleotide reductase (62, 63) may also influence viral replication. NO can also affect the viral life cycle by influencing intracellular signaling pathways regulated by oxidation of sulfhydryl groups (29). NO might bind to metal ions in viral proteins that are required for replication. Thus, a nitroso compound was shown to reduce HIV infectivity by ejecting zinc from a transcription factor that contains a zinc finger motif (64). Whereas the CVB3 genome does not contain zinc finger motifs, $\mathrm{NO}$ could conceivably influence metal ions of other transcription factors. NO can inhibit cell proliferation, but Coxsackie is a picornavirus whose replica- tion involves a viral RNA-dependent RNA polymerase and thus is not absolutely dependent upon host cell replication.

Inhibition of NOS is associated with a temporary increase in immune cell infiltration into the hearts of infected mice (Table III). Although macrophages are more prominent in hearts of treated mice after $3 \mathrm{~d}$ of infection, and although natural killer cells are more prominent in the hearts of treated mice after 3 and $5 \mathrm{~d}$ of infection, the numbers of infiltrating cells are the same after $9 \mathrm{~d}$ of infection in the hearts of treated and untreated mice. Perhaps more macrophages and natural killer cells migrate into the heart because NOS inhibition permits viral replication to increase, inducing higher levels of local cytokine production, which in turn stimulates additional macrophage and natural killer cell migration. This would support prior studies that show that macrophages and natural killer cells $(65,66)$ play a role in suppressing CVB3 replication. Thus, although other antiviral molecules are induced by viral infection, and although cells other than macrophages are involved in the host response to viral infection, NO plays a major role in defending B.10A mice from CVB3 infection.

\section{Acknowledgments}

This work was supported by grants PSA K1102451 and R01 HL53615 (C.J. Lowenstein), K01 RR0095 (S.L. Hill), and R01 33878 (N.R. Rose), all from the National Institutes of Health.

\section{References}

1. Lowenstein, C.J., and S.H. Snyder. 1992. Nitric oxide, a novel biologic messenger. Cell. 70:705-707.

2. Moncada, S., R.M. Palmer, and E.A. Higgs. 1991. Nitric oxide: physiology, pathophysiology, and pharmacology. Pharmacol. Rev. 43:109-142.

3. Ignarro, L.J. 1990. Biosynthesis and metabolism of endothelium-derived nitric oxide. Annu. Rev. Pharmacol. Toxicol. 30:535-560.

4. Nathan, C., and Q.W. Xie. 1994. Nitric oxide synthases: roles, tolls, and controls. Cell. 78:915-918.

5. Marletta, M.A. 1994. Nitric oxide synthase: aspects concerning structure and catalysis. Cell. 78:926-930.

6. Stamler, J.S. 1994. Redox signaling: nitrosylation and related target interactions of nitric oxide. Cell. 78:931-936.

7. Lowenstein, C.J., C.S. Glatt, D.S. Bredt, and S.H. Snyder. 1992. Cloned and expressed macrophage nitric oxide synthase contrasts with the brain enzyme. Proc. Natl. Acad. Sci. USA. 89:6711-6715.

8. Xie, Q.W., H.J. Cho, J. Calaycay, R.A. Mumford, K.M. Swiderek, T.D. Lee, A. Ding, T. Troso, and C. Nathan. 1992. Cloning and characterization of inducible nitric oxide synthase from mouse macrophages. Science (Wash. DC). 256:225-228.

9. Lyons, C.R., G.J. Orloff, and J.M. Cunningham. 1992. Molecular cloning and functional expression of an inducible nitric oxide synthase from a murine macrophage cell line. J. Biol. Chem. 267:6370-6374.

10. Lowenstein, C.J., E.W. Alley, P. Raval, A.M. Snowman, S.H. Snyder, S.W. Russell, and W.J. Murphy. 1993. Macrophage nitric oxide synthase gene: two upstream regions mediate induction by interferon gamma and lipopolysaccharide. Proc. Natl. Acad. Sci. USA. 90:9730-9734.

11. Xie, Q., R. Whisnant, and C. Nathan. 1993. Promoter of the mouse gene encoding calcium-independent nitric oxide synthase confers inducibility by interferon- $\gamma$ and bacterial lipopolysaccharide. J. Exp. Med. 177:1779-1784.

12. Croen, K.D. 1993. Evidence for antiviral effect of nitric oxide. Inhibition of herpes simplex virus type 1 replication. J. Clin. Invest. 91:2446-2452.

13. Karupiah, G., Q.W. Xie, R.M. Buller, C. Nathan, C. Duarte, and J.D. MacMicking. 1993. Inhibition of viral replication by interferon-gamma-induced nitric oxide synthase. Science (Wash. DC). 261:1445-1448.

14. Bi, Z., and C.S. Reiss. 1995. Inhibition of vesicular stomatitis virus infection by nitric oxide. J. Virol. 69:2208-2213.

15. Harris, N., R.M. Buller, and G. Karupiah. 1995. Gamma interferoninduced, nitric oxide-mediated inhibition of vaccinia virus replication. J. Virol. 69:910-915.

16. Springer, T.A. 1981. Monoclonal antibody analysis of complex biological systems. J. Biol. Chem. 256:3833-3839.

17. Springer, T.A., G. Galfre, D.S. Secher, and C. Milstein. 1978. Monoclonal xenogeneic antibodies to murine cell surface antigens: identification of novel leukocyte differentiation antigens. Eur. J. Immunol. 8:539-551. 
18. Sentman, C.L. 1989. Identification of a subset of murine natural killer cells that mediates rejection of $H h-1^{d}$ but not $H h-1^{b}$ bone marrow grafts. J. Exp. Med. 170:191-202.

19. Bredt, D.S., P.M. Hwang, and S.H. Snyder. 1990. Localization of nitric oxide synthase indicating a neural role for nitric oxide. Nature (Lond.). 347: $768-770$

20. Harlow, E., and D. Lane. 1988. Antibodies: A Laboratory Manual. Cold Spring Harbor Laboratory, Cold Spring Harbor, NY. 53 pp.

21. Bredt, D.S., and S.H. Snyder. 1990. Isolation of nitric oxide synthetase, a calmodulin-requiring enzyme. Proc. Natl. Acad. Sci. USA. 87:682-685.

22. Wolfgram, L.J., K.W. Beisel, A. Herskowitz, and N.R. Rose. 1986. Variations in the susceptibility to Coxsackievirus B3-induced myocarditis among different strains of mice. J. Immunol. 136:1846-1852.

23. Herskowitz, A., L.J. Wolfgram, N.R. Rose, and K.W. Beisel. 1987. Coxsackievirus B3 murine myocarditis: a pathologic spectrum of myocarditis in genetically defined inbred strains. J. Am. Coll. Cardiol. 9:1311-1319.

24. Lane, J.R., D.A. Neumann, A. Lafond Walker, A. Herskowitz, and N.R. Rose. 1992. Interleukin 1 or tumor necrosis factor can promote Coxsackie B3induced myocarditis in resistant B10.A mice. J. Exp. Med. 175:1123-1129.

25. Lane, J.R., D.A. Neumann, A. Lafond Walker, A. Herskowitz, and N.R. Rose. 1991. LPS promotes CB3-induced myocarditis in resistant B10.A mice. Cell. Immunol. 136:219-233.

26. Granger, D.L., J.B. Hibbs, Jr., and L.M. Broadnax. 1991. Urinary nitrate excretion in relation to murine macrophage activation. Influence of dietary L-arginine and oral NG-monomethyl-L-arginine. J. Immunol. 146:1294-1302.

27. Kandolf, R., P. Kirschner, D. Ameis, A. Canu, E. Erdman, H.P. Schultheiss, B. Kemkes, and P.H. Hofschneider. 1988. Enteroviral heart disease: diagnosis by in situ hybridization. In New Concepts in Viral Heart Disease. H.P. Schultheiss, editor. Springer-Verlag, Berlin. 337-348.

28. Dighiero, P., I. Reux, J.J. Hauw, A.M. Fillet, Y. Courtois, and O. Goureau. 1994. Expression of inducible nitric oxide synthase in cytomegalovirus-infected glial cells of retinas from AIDS patients. Neurosci. Lett. 166:31-34.

29. Mannick, J.B., K. Asano, K. Izumi, E. Kieff, and J.S. Stamler. 1995. Nitric oxide produced by human B lymphocytes inhibits apoptosis and EpsteinBarr virus reactivation. Cell. 79:1137-1146.

30. Bukrinsky, M.I., H.S. Nottet, H. Schmidtmayerova, L. Dubrovsky, C.R. Flanagan, M.E. Mullins, S.A. Lipton, and H.E. Gendelman. 1995. Regulation of nitric oxide synthase activity in human immunodeficiency virus type 1 (HIV-1)infected monocytes: implications for $\mathrm{HIV}$-associated neurological disease. $J$. Exp. Med. 181:735-745.

31. Liu, R.H., J.R. Jacob, J.H. Hotchkiss, P.J. Cote, J.L. Gerin, and B.C. Tennant. 1994. Woodchuck hepatitis virus surface antigen induces nitric oxide synthesis in hepatocytes: possible role in hepatocarcinogenesis. Carcinogenesis (Oxf.). 15:2875-2877.

32. Lefer, A.M., P.S. Tsao, X.L. Ma, and T.K. Sampath. 1992. Antiischaemic and endothelial protective actions of recombinant human osteogenic protein (hOP-1). J. Mol. Cell. Cardiol. 24:585-593.

33. Egdell, R.M., T. Siminiak, and D.J. Sheridan. 1994. Modulation of neutrophil activity by nitric oxide during acute myocardial ischaemia and reperfusion. Basic Res. Cardiol. 89:499-509.

34. Niu, X.F., C.W. Smith, and P. Kubes. 1994. Intracellular oxidative stress induced by nitric oxide synthesis inhibition increases endothelial cell adhesion to neutrophils. Circ. Res. 74:1133-1140.

35. Ma, X.L., A.S. Weyrich, D.J. Lefer, and A.M. Lefer. 1993. Diminished basal nitric oxide release after myocardial ischemia and reperfusion promotes neutrophil adherence to coronary endothelium. Circ. Res. 72:403-412.

36. Fortier, A.H., T. Polsinelli, S.J. Green, and C.A. Nacy. 1992. Activation of macrophages for destruction of Francisella tularensis: identification of cytokines, effector cells, and effector molecules. Infect. Immun. 60:817-825.

37. Denis, M. 1991. Interferon-gamma-treated murine macrophages inhibit growth of tubercle bacilli via the generation of reactive nitrogen intermediates. Cell. Immunol. 132:150-157.

38. Adams, L.B., S.G. Franzblau, Z. Vavrin, J.B. Hibbs, Jr., and J.L. Krahenbuhl. 1991. L-Arginine-dependent macrophage effector functions inhibit metabolic activity of Mycobacterium leprae. J. Immunol. 147:1642-1646.

39. Beckerman, K.P., H.W. Rogers, J.A. Corbett, R.D. Schreiber, M.L. McDaniel, and E.R. Unanue. 1993. Release of nitric oxide during the T cellindependent pathway of macrophage activation. Its role in resistance to Listeria monocytogenes. J. Immunol. 150:888-895.

40. MacMicking, J.D., C. Nathan, G. Hom, N. Chartrain, D.S. Fletcher, M. Trumbauer, K. Stevens, Q.W. Xie, K. Sokol, N. Hutchinson, et al. 1995. Altered responses to bacterial infection and endotoxic shock in mice lacking inducible nitric oxide synthase. Cell. 81:641-650.

41. Wei, X.Q., I.G. Charles, A. Smith, J. Ure, C.J. Feng, F.P. Huang, D.M. $\mathrm{Xu}, \mathrm{W}$. Muller, S. Moncada, and F.Y. Liew. 1995. Altered immune responses in mice lacking inducible nitric oxide synthase. Nature (Lond.). 375:408-411.

42. Henke, A., H.P. Spengler, A. Stelzner, M. Nain, and D. Gemsa. 1992. Lipopolysaccharide suppresses cytokine release from coxsackie virus infected human monocytes. Res. Immunol. 143:65-70.

43. Lane, J.R., D.A. Neumann, A. Lafond-Walker, A. Herskowitz, and N.R. Rose. 1993. Role of IL-1 and tumor necrosis factor in coxsackie virus- induced autoimmune myocarditis. J. Immunol. 151:1682-1686.

44. Henke, A., C. Mohr, H. Sprenger, C. Graebner, A. Stelzner, M. Nain, and D. Gemsa. 1992. Coxsackievirus B3 induced production of tumor necrosis factor-alpha, IL-1 beta, and IL-6 in human monocytes. J. Immunol. 148:22702277.

45. Ungureanu-Longrois, D., J.L. Balligand, W.W. Simmons, I. Okada, L. Kobzik, C.J. Lowenstein, S.L. Kunkel, T. Michel, R.A. Kelly, and T.W. Smith. 1995. Induction of nitric oxide synthase activity by cytokines in ventricular myocytes is necessary but not sufficient to decrease contractile responsiveness to beta-adrenergic agonists. Circ. Res. 77:494-502.

46. Balligand, J.L., D. Ungureanu-Longrois, W.W. Simmons, D. Pimental, T.A. Malinski, M. Kapturczak, Z. Taha, C.J. Lowenstein, A.J. Davidoff, and R.A. Kelly. 1994. Cytokine-inducible nitric oxide synthase (iNOS) expression in cardiac myocytes. Characterization and regulation of iNOS expression and detection of iNOS activity in single cardiac myocytes in vitro. J. Biol. Chem. 269:27580-27588.

47. Pinsky, D.J., B. Cai, X. Yang, C. Rodriguez, R.R. Sciacca, and P.J. Cannon. 1995. The lethal effects of cytokine-induced nitric oxide on cardiac myocytes are blocked by nitric oxide synthase antagonism or transforming growth factor beta. J. Clin. Invest. 95:677-685.

48. Yang, X, N. Chowdhury, B. Cai, J. Brett, C. Marboe, R. R. Sciacca, R.E. Michler, and P.J. Cannon. 1994. Induction of myocardial nitric oxide synthase by cardiac allograft rejection. J. Clin. Invest. 94:714-721.

49. Russell, M.E., A.F. Wallace, L.R. Wyner, J.B. Newell, and M.J. Karnovsky. 1995. Upregulation and modulation of inducible nitric oxide synthase in rat cardiac allografts with chronic rejection and transplant arteriosclerosis. Circulation. 92:457-464.

50. Worrall, N.K., W.D. Lazenby, T.P. Misko, T.S. Lin, C.P. Rodi, P.T. Manning, R.G. Tilton, J.R. Williamson, and T.B. Ferguson, Jr. 1995. Modulation of in vivo alloreactivity by inhibition of inducible nitric oxide synthase. $J$. Exp. Med. 181:63-70.

51. Kots, A.Y., A.V. Skurat, E.A. Sergienko, T.V. Bulargina, and E.S. Severin. 1992. Nitroprusside stimulates the cysteine-specific mono (ADP-ribosylation) of glyceraldehyde-3-phosphate dehydrogenase from human erythrocytes. FEBS Lett. 300:9-12.

52. Zhang, J., and S.H. Snyder. 1993. Purification of a nitric oxide-stimulated ADP-ribosylated protein using biotinylated beta-nicotinamide adenine dinucleotide. Biochemistry. 32:2228-2233.

53. Brune, B., and E.G. Lapetina. 1989. Activation of a cytosolic ADP-ribosyltransferase by nitric oxide-generating agents. J. Biol. Chem. 264:8455-8458.

54. Brune, B., and E.G. Lapetina. 1990. Properties of a novel nitric oxidestimulated ADP-ribosyltransferase. Arch. Biochem. Biophys. 279:286-290.

55. Mateo, R.B., J.S. Reichner, B. Mastrofrancesco, D. Kraft-Stolar, and J.E. Albina. 1995. Impact of nitric oxide on macrophage glucose metabolism and glyceraldehyde-3-phosphate dehydrogenase activity. Am. J. Phys. 268: C669-C675.

56. Welsh, N., D.L. Eizirik, K. Bendtzen, and S. Sandler. 1991. Interleukin-1 beta-induced nitric oxide production in isolated rat pancreatic islets requires gene transcription and may lead to inhibition of the Krebs cycle enzyme aconitase. Endocrinology. 129:3167-3173.

57. Kilbourn, R.G., J. Klostergaard, and G. Lopez-Bernstein. 1984. Activated macrophages secrete a soluble factor that inhibits mitochondrial respiration of tumor cells. J. Immunol. 133:2577-2581.

58. Bolanos, J.P., S. Peuchen, S.J. Heales, J.M. Land, and J.B. Clark. 1994. Nitric oxide-mediated inhibition of the mitochondrial respiratory chain in cultured astrocytes. J. Neurochem. 63:910-916.

59. Wink, D.A., K.S. Kasprzak, C.M. Maragos, R.K. Elespuru, M. Misra T.M. Dunams, T.A. Cebula, W.H. Koch, A.W. Andrews, J.S. Allen, et al. 1991. DNA deaminating ability and genotoxicity of nitric oxide and its progenitors. Science (Wash. DC). 254:1001-1003.

60. Nguyen, T., D. Brunson, C.L. Crespi, B.W. Penman, J.S. Wishnok, and S.R. Tannenbaum. 1992. DNA damage and mutation in human cells exposed to nitric oxide in vitro. Proc. Natl. Acad. Sci. USA. 89:3030-3034.

61. Esumi, H., and S.R. Tannenbaum. 1994. U.S.-Japan Cooperative Cancer Research Program: seminar on nitric oxide synthase and carcinogenesis. Cancer Res. 54:297-301.

62. Lepoivre, M., F. Fieschi, J. Coves, L. Thelander, and M. Fontecave. 1991. Inactivation of ribonucleotide reductase by nitric oxide. Biochem. Biophys. Res. Commun. 179:442-448.

63. Kwon, N.S., D.J. Stuehr, and C.F. Nathan. 1991. Inhibition of tumor cell ribonucleotide reductase by macrophage derived nitric oxide. J. Exp. Med. 174: 761-768.

64. Rice, W.G., C.A. Schaeffer, B. Harten, F. Villinger, T.L. South, M.F Summers, L.E. Henderson, J.W. Bess, Jr., L.O. Arthur, J.S. McDougal, et al 1993. Inhibition of HIV-1 infectivity by zinc-ejecting aromatic C-nitroso compounds. Nature (Lond.). 361:473-475.

65. Godeny, E.K., and C.J. Gauntt. 1986. Involvement of natural killer cells in coxsackievirus B3 induced murine myocarditis. J. Immunol. 137:1670-1695.

66. Godeny, E.K., and C.J. Gauntt. 1987. Murine natural killer cells limit coxsackievirus B3 replication. J. Immunol. 139:913-920. 